\title{
Reduction of $\mathrm{Cr}(\mathrm{VI})$ using indigenous Aspergillus spp. isolated from heavy metal contaminated sites
}

\section{De Sotto $\mathbf{R}^{1}$, Monsanto $\mathrm{RZ}^{1}$, Edora $\mathrm{JL}^{\mathbf{1}}$, Bautista $\mathbf{R H}^{\mathbf{1}}$, Bennett $\mathbf{R M}^{\mathbf{2}}$, and Dedeles GR ${ }^{1}$}

\begin{abstract}
${ }^{I}$ Department of Biological Sciences, College of Science, University of Santo Tomas, Manila, Philippines
${ }^{2}$ Laboratory of Pure and Applied Microbiology, Research Center for the Natural and Applied Sciences, University of Santo Tomas, Manila, Philippines
\end{abstract}

De Sotto R, Monsanto R, Edora J, Bautista RH, Bennett RM, Dedeles GR 2015 - Reduction of $\mathrm{Cr}(\mathrm{VI})$ using indigenous Aspergillus spp. isolated from heavy metal contaminated sites. Mycosphere 6(1), 53-59, Doi 10.5943/mycosphere/6/1/6

\begin{abstract}
Fifteen (15) fungal morphospecies isolated from heavy metal contaminated sites were assayed for $\mathrm{Cr}(\mathrm{VI})$-tolerance in nutrient scarce PDB medium. Of the 15 isolates, Aspergillus sp. MSG7 and Aspergillus sp. BP3 tolerated $1440 \mathrm{mg} / \mathrm{L} \mathrm{Cr}(\mathrm{VI})$ and $1800 \mathrm{mg} / \mathrm{L}$ for Aspergillus sp. BP2 and Aspergillus sp. BP5. Further, in vitro $\mathrm{Cr}(\mathrm{VI})$ reduction using mycelial balls in reactor tubes with 1/10 strength PDB were assayed at varying $\mathrm{Cr}(\mathrm{VI})$ concentrations $(90,180,360,720$ and 1440 $\mathrm{mg} / \mathrm{L})$ at $\mathrm{pH} 2.0$ and at varying $\mathrm{pH}(1.0-4.0)$ with $360 \mathrm{mg} / \mathrm{L} \mathrm{Cr}(\mathrm{VI})$. Reactor tubes were incubated at room temperature with shaking at $150 \mathrm{rpm}$ and residual $\mathrm{Cr}(\mathrm{VI})$ was quantified using $\mathrm{UV}-\mathrm{Vis}$ spectrophotometer at $\mathrm{OD}_{540 \mathrm{~nm}}$ following 1,5-Diphenylcarbazide (DPCZ) method. Isolates showed $\mathrm{Cr}(\mathrm{VI})$ reduction of $30-65 \%$ with culture factors as not significant $(p>0.05)$. This signified that isolates were able to tolerate and reduce $\mathrm{Cr}(\mathrm{VI})$ within the utilized $\mathrm{pH}$ levels and $\mathrm{Cr}(\mathrm{VI})$ concentration effectively. The findings indicates the potential biotechnological application of the four fungal isolates in reducing $\mathrm{Cr}(\mathrm{VI})$ in broth medium
\end{abstract}

Key words - Aspergillus sp. - Cr (VI) - reduction

\section{Introduction}

Heavy metal pollution is one of the most prevalent environmental problems. It is due to rapid industrialization and unsystematic dumping of industrial wastes directly to terrestrial and aquatic systems (Blacksmith institute 2007, Doble \& Mishra 2007). Of the common heavy metal contaminants, hexavalent chromium or $\mathrm{Cr}(\mathrm{VI})$ is prevalent in various river systems in the Philippines due to effluents coming from leather tanning companies. $\mathrm{Cr}(\mathrm{VI})$ predominantly exists in nature as chromates $\left(\mathrm{CrO}_{4}{ }^{2-}\right)$ and dichromates $\left(\mathrm{Cr}_{2} \mathrm{O}_{7}{ }^{2-}\right)$ and are used in industrial processes like metallic alloy manufacturing, leather tanning, chromate preparation, electroplating, metal finishing, and mining (Francisco et al. 2002, Srivastava \& Thakur 2006). Since Cr(VI) is easily absorbed, it is approximately 100-fold more toxic amongst known $\mathrm{Cr}$ oxidation states, thus, given attention for its mutagenic, carcinogenic, teratogenic and other long-term adverse effects (Darrie 2001, Francisco et al. 2002). Various conventional methods like chemical precipitation, membrane separation, ion exchange and evaporation are employed to remove $\mathrm{Cr}(\mathrm{VI})$ in the environment. However, these 
technologies are costly and generate secondary pollution (Prigione et al. 2009). Through the emerging technologies of bioremediation, fungal species are effective biomaterials of heavy metal biotransformation and biosorption by converting their toxic state to lesser or non-toxic forms and complete metal absorption (Park et al. 2005, Srivastava \& Thakur, 2006). Amongst recent biomaterials, fungi receive increased attention for heavy metal removal and recovery for it produces high biomass yield and are easily manipulated. Further, recent studies showed diverse strains isolated from contaminated sites with excellent ability to remove significant metal quantities both on aqueous solutions and effluents (Bennett et al. 2013, Ezzouhri et al. 2009). Thus, this study isolated, characterized and identified $\mathrm{Cr}(\mathrm{VI})$ resistant fungi from different heavy metal contaminated sites and tested their ability for $\mathrm{Cr}(\mathrm{VI})$ tolerance and reduction at varying $\mathrm{pH}$ and Cr(VI) concentration.

\section{Materials \& Methods}

\section{Isolation of $\mathrm{Cr}(\mathrm{VI})$ resistant fungi}

Heavy metal contaminated soil samples were collected at Coto Chromite Deposit in Masinloc, Zambales and Motolite Battery Plant in Novaliches, Quezon City. Samples were placed in sealed bags kept at room temperature and labeled properly. One gram of each soil sample was serially diluted to $10^{-3}$ and spread plated to $1 / 2$ strength Potato Dextrose Agar (PDA) amended with $500 \mathrm{mg} / \mathrm{L}$ streptomycin sulphate and $1 \mathrm{mg} / \mathrm{L} \mathrm{Cr}(\mathrm{VI})$. Plates were incubated at room temperature for 3-5 days in triplicates. Fungal colonies on PDA plates were successively purified in PDA slants using spore touch method and incubated at room temperature for 3-5 days. Axenic fungal isolates in Czapex-Dox agar or PDA were characterized microscopically at $400 \times-1000 \times$ for identification.

\section{$\operatorname{Cr}(V I)$ tolerance assay}

A set of $1 / 10$ strength Potato Dextrose Broth (PDB) in triplicates amended with $\mathrm{Cr}(\mathrm{VI})$ concentrations from $360-1800 \mathrm{mg} / \mathrm{L}$ were inoculated with standardized spores $\left(10^{3}-10^{4}\right.$ spores $/ \mathrm{ml}$ ) of axenic isolates. Tubes were incubated at room temperature for 3-5 days in rotary shaker at $200 \mathrm{rpm}$ and plated at day 5 in PDA for cell viability test with $\mathrm{Cr}(\mathrm{VI})$. Control samples were prepared by inoculating isolates in PDA plates without $\mathrm{Cr}(\mathrm{VI})$.

\section{$\mathrm{Cr}(\mathrm{VI})$ reduction assay and statistical test}

One milliliter of standardized spore suspension $\left(10^{3}-10^{4}\right.$ spores $\left./ \mathrm{ml}\right)$ was inoculated in 299 $\mathrm{ml}$ PDB. Cultures were incubated for 5 days at room temperature with shaking at $150 \mathrm{rpm}$ forming mycelial balls. Mycelia were harvested and placed in $50 \mathrm{ml}$ falcon tubes with sterile distilled water and centrifuged at 10,000 rpm for 5 mins. Supernatant was decanted aseptically and mycelia were re-washed three times with sterile distilled water. A $1 \mathrm{~g}$ mycelial ball of each isolate was inoculated in tubes with $1 / 10$ strength PDB amended with $360 \mathrm{mg} / \mathrm{L} \mathrm{Cr}(\mathrm{VI})$ under varying $\mathrm{pH}(\mathrm{pH} 1.0-4.0$ ) incubated at room temperature. In another set up of 1/10 strength PDB, $1 \mathrm{~g}$ mycelial ball was added to different tubes with varying $\mathrm{Cr}(\mathrm{VI})$ concentrations $(180,360,720$ and $1440 \mathrm{mg} / \mathrm{L})$ at $\mathrm{pH} 2.0$ incubated at room temperature. A $1 \mathrm{ml}$ spent broth medium of both set-up sampled at days $0,1,3$, and 5 were extracted off and $1000 \mu 1$ 1,5-Diphenylcarbazide $(0.5 \mathrm{~g}$ 1,5-DPCZ in $100 \mathrm{ml}$ absolute ethanol and $400 \mathrm{ml} 3.6 \mathrm{~N} \mathrm{H}_{2} \mathrm{SO}_{4}$ ) was added until formation of violet complex analyzed at $\mathrm{OD}_{540 \mathrm{~nm}}$ (Lambda 35, perkin elmer UV-Vis spectrophotometer). Percentage $\mathrm{Cr}(\mathrm{VI})$ reduction was computed as (Bennett et al. 2013):

$$
C_{P R}=\left(I_{a b s}-F_{a b s}\right) / I_{a b s} \times 100
$$

Where $C_{P R}$ is the percentage $\mathrm{Cr}(\mathrm{VI})$ reduction, $I_{a b s}$ is the absorbance of control and $F_{a b s}$ for the absorbance of experimental samples. All samples were prepared in triplicates. Respective control samples were prepared in all experimental set-ups. Results were analyzed statistically amongst and between mean of data samples with variance analysis at $95 \%$ level of confidence. 


\section{Results}

A total of 15 fungal (Table 1) morphospecies were isolated from two sampling sites (Coto Chromite Deposit in Masinloc, Zambales and Motolite Battery Plant in Novaliches, Quezon City). Of the 15 morphospecies, 2 isolates tolerated $1440 \mathrm{mg} / \mathrm{L}$ (Aspergillus sp. MSG7 and Aspergillus sp. BP3) while another two species (Aspergillus sp. BP2 and Aspergillus sp. BP5) tolerated 1800 $\mathrm{mg} / \mathrm{L}$. Further, cell viability test affirmed isolates viability when cultured in nutrient scarce medium (1/10 strength PDB and PDA) amended with high levels of $\mathrm{Cr}(\mathrm{VI})$, thus, suggesting the biotechnological significance of the four isolates.

Table 1 Summary of fungal isolates and $\mathrm{Cr}(\mathrm{VI})$ tolerance

\begin{tabular}{cccc}
\hline $\begin{array}{c}\text { Isolate } \\
\text { code }\end{array}$ & Source & $\begin{array}{c}\text { Cr(VI) } \\
\text { tolerance }\end{array}$ & Identity \\
\hline MSG1 & Masinloc, Zambales & 720 & - \\
MSG2 & Masinloc, Zambales & 720 & - \\
MSG3 & Masinloc, Zambales & 720 & - \\
MSG4 & Masinloc, Zambales & 720 & - \\
MSG5 & Masinloc, Zambales & 720 & - \\
MSG6 & Masinloc, Zambales & 720 & - \\
MSG7 & Masinloc, Zambales & 1440 & Aspergillus sp. \\
MSG8 & Masinloc, Zambales & 720 & - \\
MSG9 & Masinloc, Zambales & 720 & - \\
BP1 & Novaliches, Quezon City & 720 & Aspergillus sp. \\
BP2 & Novaliches, Quezon City & 1800 & Aspergillus sp. \\
BP3 & Novaliches, Quezon City & 1440 & - \\
BP4 & Novaliches, Quezon City & 360 & Aspergillus sp. \\
BP5 & Novaliches, Quezon City & 1800 & - \\
BP6 & Novaliches, Quezon City & 720 & \\
\hline - not determined & &
\end{tabular}

\section{$\mathrm{Cr}(\mathrm{VI})$ reduction assay}

Statistically, there were no significant difference $(p>0.05)$ for $\mathrm{Cr}(\mathrm{VI})$ reduction when mycelial balls were subjected to varying $\mathrm{pH}$ levels $(\mathrm{pH} 1.0-5.0)$ at $360 \mathrm{mg} / \mathrm{L} \mathrm{Cr}(\mathrm{VI})$ (Figure 1) and at varying $\mathrm{Cr}(\mathrm{VI})$ concentrations, $\mathrm{pH} 2.0$ (Figure 2) both incubated at room temperature.

In Figure 1, acidic $\mathrm{pH}$ was inferred as important factor for fungal $\mathrm{Cr}(\mathrm{VI})$ reduction due to conversion of anionic $\mathrm{Cr}(\mathrm{VI})$ complex at $\mathrm{pH} \leq 5.0$ (Bennett et al. 2013). Based from our results, fungal isolates showed no significant difference $(p>0.05)$ regardless of $\mathrm{pH}$, as grouping factor, in media amended with $360 \mathrm{mg} / \mathrm{L} \mathrm{Cr}(\mathrm{VI})$. However, based on rank, $\mathrm{pH} 1.0$ showed highest reduction followed by $\mathrm{pH}$ 2.0. Further, amongst four fungal species as statistical grouping factor, it showed no significant difference $(p>0.05)$ indicating similar $\mathrm{Cr}(\mathrm{VI})$ reduction abilities. This indicates that regardless of species, reduction was shown efficient $[30-68 \% \mathrm{Cr}(\mathrm{VI})$ reduction] and that binding properties of fungal cell wall played an important factor in $\mathrm{Cr}(\mathrm{VI})$ reduction.

Based on Figure 2 with $\mathrm{Cr}(\mathrm{VI})$ concentration as grouping factor, $\mathrm{Cr}(\mathrm{VI})$ reduction showed no significant difference $(p>0.05)$. This indicates that $\mathrm{Cr}(\mathrm{VI})$ did not affect growth and viability of fungal species within the utilized Cr(VI) concentration levels $(180-1440 \mathrm{mg} / \mathrm{L})$. Further, amongst four species, $\mathrm{Cr}(\mathrm{VI})$ was found non-significant $(p>0.05)$. This indicates that cell wall properties of fungal isolates play an important factor in $\mathrm{Cr}(\mathrm{VI})$ reduction process. Thus, $\mathrm{Cr}(\mathrm{VI})$ reduction [35 $65 \% \mathrm{Cr}(\mathrm{VI})$ reduction] was efficient regardless of isolates and $\mathrm{Cr}(\mathrm{VI})$ concentration. 


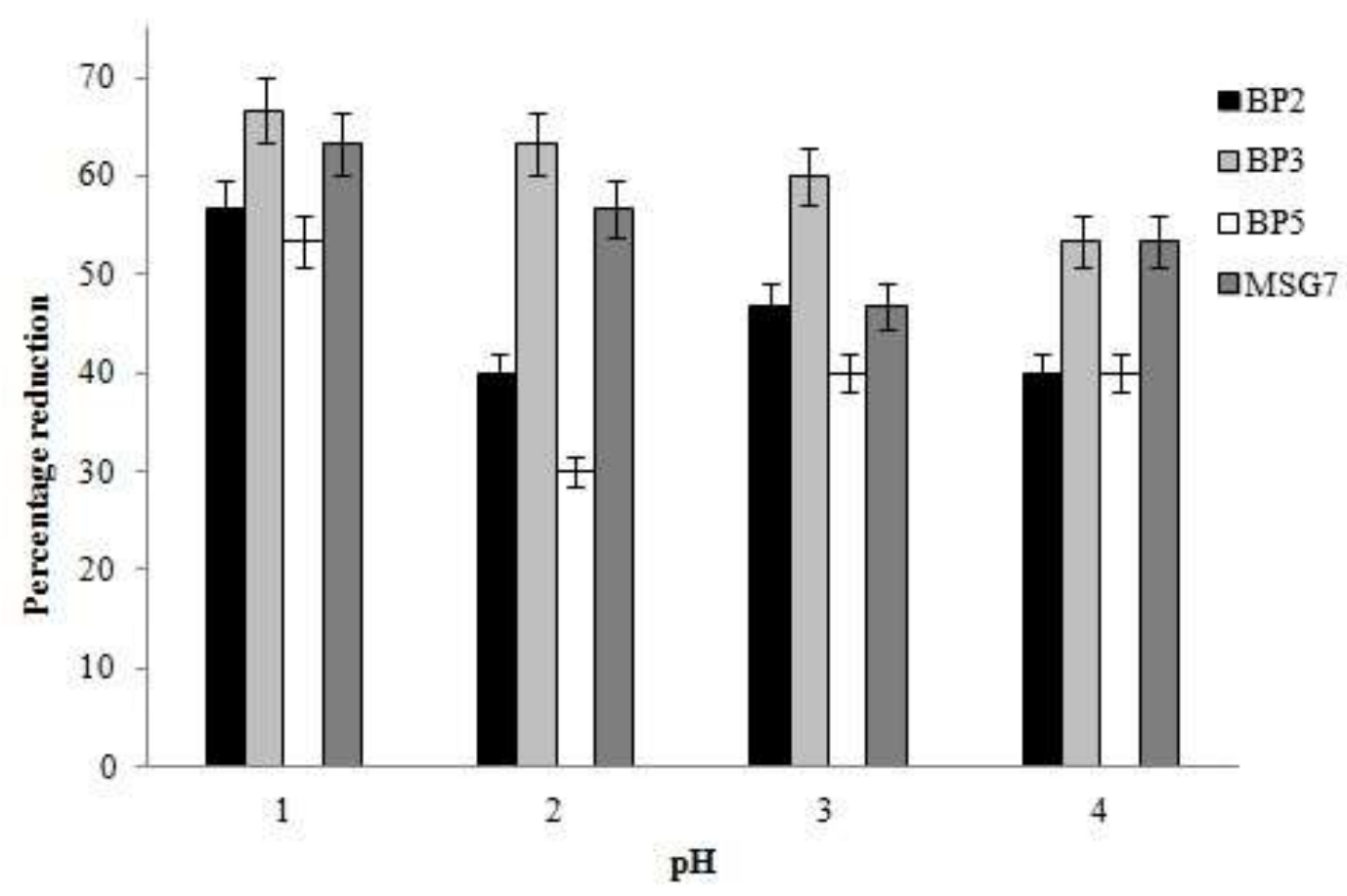

Fig. 1 - Percentage reduction of $360 \mathrm{mg} / \mathrm{L} \mathrm{Cr}(\mathrm{VI})$ at varying $\mathrm{pH}$ levels

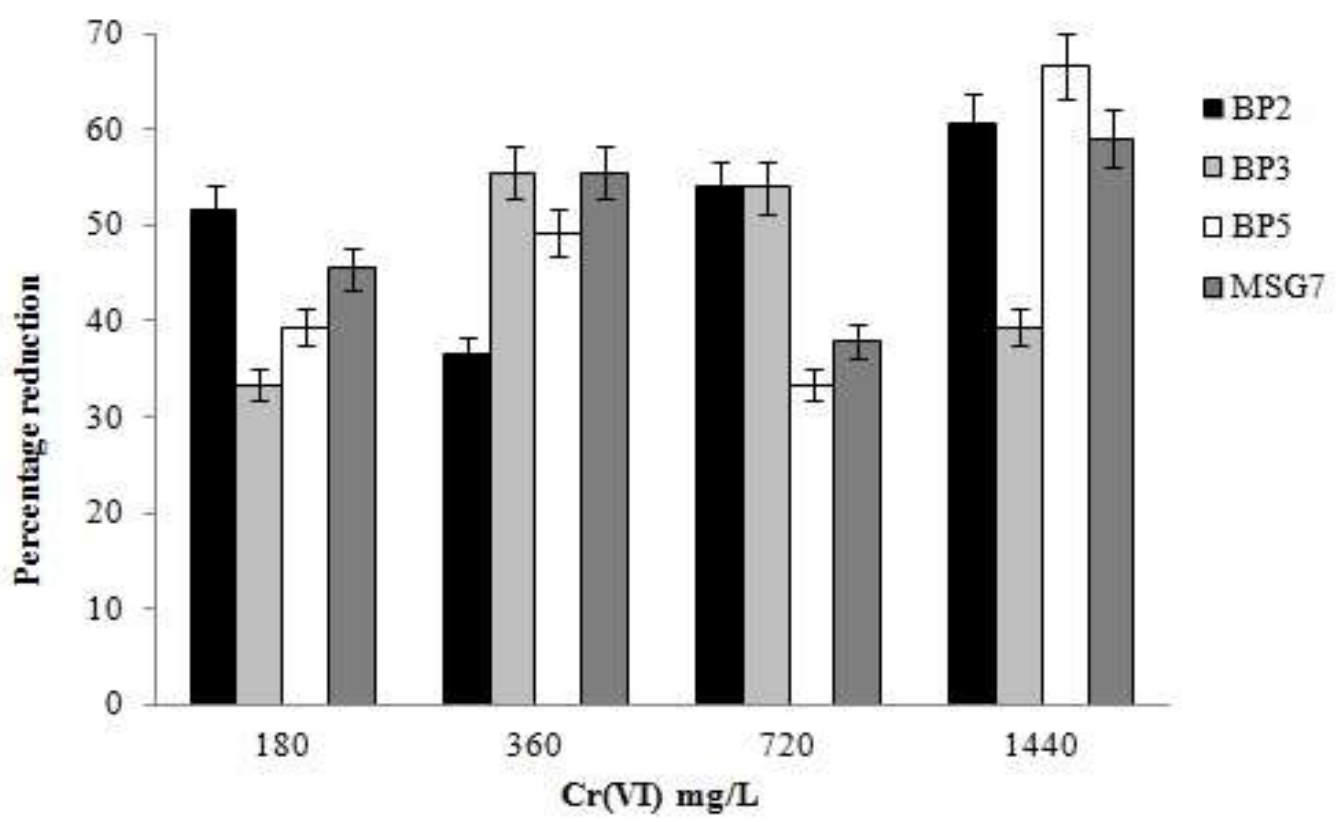

Fig. 2 - Percentage reduction of varying $\mathrm{Cr}(\mathrm{VI})$ concentrations at $\mathrm{pH} 2.0$

\section{Discussion}

Studies on industrial application of fungal species are of recent relevance due to their ubiquitous and metabolic nature. Fungi can adapt and grow at extreme conditions of $\mathrm{pH}$, temperature, scarce nutrient and high metal concentrations. They have excellent cell wall metalbinding receptors for various heavy metals. Generally, fungal species developed remarkable tolerance to heavy metals when exposed to high metal concentrations leading to mutation and adaptation (Ezzouhri et al. 2009, Valix et al. 2001). This explains why our local isolates tolerated high $\mathrm{Cr}(\mathrm{VI})$ levels (1440 and $1800 \mathrm{mg} / \mathrm{L})$ under nutrient-scarce medium, since, our sampling sites 
are contaminated with both chromium and lead. It was further supported by Muñoz et al. (2012) that collection sites with extensive metal contaminants contribute to resistance of microorganisms to heavy metals. In the study of Kumar et al. (2012), Aspergillus niger, A. sydoni, Penicillium janthinellum and Trichoderma viridae were able to tolerate high levels of $\mathrm{Ni}(\mathrm{II}), \mathrm{Zn}(\mathrm{II})$ and $\mathrm{Cr}(\mathrm{VI})$. Further, Penicillum funiculosum, P. simplicissimum and Aspergillus foetidus gained resistance when continuously subcultred in agarised media supplemented with heavy metals (Valix et al. 2001). Fungi can develop high resistance to heavy metals through adsorption to cell surfaces, complexation by exopolysaccharides, intracellular accumulation and precipitation (Massaccesi et al. 2002, Saxena et al. 2006). The ability of fungi as biosorbents has been extensively evaluated and showed excellent metal sequestering abilities for heavy metals such as cadmium, chromium, copper, zinc, lead, iron, nickel, silver and uranium from aqueous solution (Ahluwalia \& Goyal 2007, Bennett et al. 2013, Kapoor \& Viraraghavan 1995, Mungasavalli et al. 2007). Both living and dead fungi are effective in removing metals, but dead cells are preferable for wastewater treatment since they are not affected by toxic wastes and chemicals (Prigione et al. 2009). Thus, heavy metals passively transports into fungal biomasses. In this study, mycelial balls were utilized as $\mathrm{Cr}(\mathrm{VI})$ reduction and sorption agents to test whether a $\mathrm{Cr}(\mathrm{VI})$-metabolic independent interaction transpired (Ahalya et al. 2003). The most important parameter influencing fungal sorption was $\mathrm{pH}$. It changes cell wall charges in presence of excess $\mathrm{H}^{+}$or $\mathrm{OH}^{-}$ions. Some advantages of acidic medium in $\mathrm{Cr}(\mathrm{VI})$ reduction are; first, fungal cell wall becomes highly protonated due to excess $\mathrm{H}^{+}$ions that binds to functional groups $\left(-\mathrm{OH},-\mathrm{NH}_{2}\right.$, and $-\mathrm{C}=\mathrm{O}$ with $\left.-\mathrm{NH}\right)$ (Bennett et al. 2013); and second, $\mathrm{Cr}(\mathrm{VI})$ forms its anionic species to $\mathrm{HCrO}^{4-}, \mathrm{CrO}_{4}{ }^{2-}$ and $\mathrm{Cr}_{2} \mathrm{O}_{7}{ }^{2-}$ (Bennett et al. 2013, Sanghi et al. 2009). In the process of $\mathrm{Cr}(\mathrm{VI})$ reduction under acidic condition, key steps were elucidated similar to previous reports; first, formation of anionic species $\left(\mathrm{HCrO}^{4-}, \mathrm{CrO}_{4}{ }^{2-}\right.$ and $\left.\mathrm{Cr}_{2} \mathrm{O}_{7}{ }^{2-}\right)$ of $\mathrm{Cr}(\mathrm{VI})$; second, binding of negatively charged anionic $\mathrm{Cr}(\mathrm{VI})$ species to highly protonated fungal cell wall; third, conversion of $\mathrm{Cr}(\mathrm{VI})$ to $\mathrm{Cr}(\mathrm{III})$; and lastly, repulsion of $\mathrm{Cr}$ (III) back into broth medium due to similarities in charges (Bennett et al. 2013, Sanghi et al. 2009), since Cr(III) has no ability to form its anionic equivalents. In our set-up, it was theorized that $\mathrm{Cr}(\mathrm{III})$ transpired in broth medium following the principle of $\mathrm{Cr}(\mathrm{VI})-\mathrm{Cr}$ (III) biotransformation mechanism as mediated by electron donors present in fungal cell wall. This explain why $\mathrm{pH}$ showed no significant effect $(p>0.05)$ when used as grouping factor since, $\mathrm{pH} 1.0-4.0$ statistically resulted to similar $\mathrm{Cr}(\mathrm{VI})$ coupled reduction and biotransformation mechanism. Our results showed similar data from findings of Bennett et al. (2013) in which Aspergillus sp. and Aspergillus niger efficiently reduced $\mathrm{Cr}(\mathrm{VI})$ within $\mathrm{pH} 2.0-7.0$, and $\mathrm{pH} 2.0$ and 5.5 for Paecilomyces lilacinus (Kumar et al. 2012, Sharma \& Adholya 2011). The study further affirmed and established the $\mathrm{Cr}(\mathrm{VI})-\mathrm{Cr}$ (III)-fungal cell wall chemistry occurring amongst Aspergillus spp. as previously described by several publications. $\mathrm{Cr}(\mathrm{VI})$ concentration showed no significant effect $(p>0.05)$ on $\mathrm{Cr}(\mathrm{VI})$ reduction in broth medium. Since, fungal isolates functioned as $\mathrm{Cr}(\mathrm{VI})$-sorbing/reducing agent and not as developing mycelia. This infers the metabolic independent type of interaction to $\mathrm{Cr}(\mathrm{VI})$ (Ahalya et al. 2003). The functional groups of fungal cell wall and $\mathrm{Cr}(\mathrm{VI})$ underwent a physico-chemical interaction as mediated by the conversion of $\mathrm{Cr}(\mathrm{VI})$ to $\mathrm{Cr}(\mathrm{III})$ via fungal-cell wall sequestration and biotransformation. In this case, our local isolates converted the toxic $\mathrm{Cr}(\mathrm{VI})$ to its non- to lesser toxic $\mathrm{Cr}$ (III) form. Further, increased surface mycelial biomass efficiently reduce and transform $\mathrm{Cr}(\mathrm{VI})$ in broth medium as attributed to large surface area of binding sites of fungal cell wall (Sahin \& Ozturk 2004).

\section{Conclusion}

Based on the construed data, it showed the ability of Aspergillus spp. to tolerate high $\mathrm{Cr}(\mathrm{VI})$ concentrations and efficiently reduce $\mathrm{Cr}(\mathrm{VI})$ under nutrient scarce condition. Further, $\mathrm{pH}$ showed to be an important factor in $\mathrm{Cr}(\mathrm{VI})$ reduction and absorption based on statistical data on percentage reduction. With the aforementioned data, it affirms the potential of the isolates in absorbing and reducing $\mathrm{Cr}(\mathrm{VI})$ in natural systems. 


\section{Acknowledgements}

The authors acknowledge Dr. Irineo J. Dogma Jr for technical assistance and RCNAS for the laboratory equipment.

\section{References}

Ahalya N, Ramachandra TV, Kanamadi RD. 2003 - Biosorption of Heavy Metals. Research Journal of Chemistry and Environment. 7(4), 71-79.

Ahluwalia SS, Goyal D. 2007 - Microbial and plant derived biomass for removal of heavy metals from wastewater. Bioresource Technology. 98(12), 2243-2257.

Bennett RM, Cordero PRF, Bautista GS, Dedeles GR. 2013 - Reduction of hexavalent chromium using bacteria and fungi isolated from contaminated soil and water samples. Chemistry and Ecology. 29(4), 320-328.

Blacksmith Institute. 2007 - World's worst polluted places: the dirty thirty. http://www.blacksmithinstitute.org

Darrie G. 2001 - Commercial extraction technology and process waste disposal in the manufacture of chromium chemicals from ore. Environmental Geochemistry and Health. 23(3), 187-193.

Doble M, Mishra S. 2007 - Novel chromium tolerant microorganisms: isolation, characterization and their biosorption capacity. Ecotoxicology and Environmental Safety. 71(3), 874-879.

Ezzouhri L, Castro E, Moya M, Espinola F, Lairini K. 2009 - Heavy metal tolerance of filamentous fungi isolated from polluted sites in Tangier, Morocco. African Journal of Microbiological Research. 3(2), 35-48.

Kapoor A, Viraraghavan T. 1995 - Fungal biosorption - an alternative treatment option for heavy metal bearing wastewater: a review. Bioresource Technology. 53(2), 195-206.

Kumar R, Bhatia D, Singh R, Bishnoi NR. 2012 - Metal tolerance and sequestration of Ni, Zn and $\mathrm{Cr}$ ions from stimulated and electroplating wastewater in batch process: kinetics and equilibrium study. International Biodeterioration and Biodegradation. 66, 82-90.

Francisco R, Alpoim MC, Morais PV. 2002 - Diversity of chromium resistant and reducing bacteria in a chromium contaminated activated sludge. Journal of Applied Microbiology. 92(5), 837-843

Massaccesi G, Romero MC, Cazau MC, Bucsinszky AM. 2002 - Cadmium removal capacities of filamentous soil fungi isolated from industrially polluted sediments, in La Plata (Argentina). World Journal of Microbiology and Biotechnology. 18(4), 817-820.

Mungasavalli DP, Viraraghavan T, Jin YC. 2007 - Biosorption of chromium from aqueous solutions by pretreated Aspergillus niger: batch and column studies. Colloids and Surfaces A: physicochemical engineering aspects. 301(1-3), 214-223.

Muñoz AJ, Ruiz E, Abriouel H, Gálvez A, Ezzouhri L, Lairini K, Espínola F. 2012 - Heavy metal tolerance of microorganisms isolated from wastewaters: identification and evaluation of its potential for biosorption. Chemical Engineering Journal. 210, 325-332

Park JM, Jo JH, Park D, Yun YS. 2005 - Mechanism of hexavalent chromium removal by dead fungal biomass of Aspergillus niger. Water Research. 39(4), 533-540.

Prigione V, Zerlottin M, Refosco D, Tigini V, Anastasia A, Varese GC. 2009 - Chromium removal from a real tanning effluent by autochthonous and allochthonous Fungi. Bioresource Technology. 100(11), 2770-2776

Sahin Y, Ozturk A. 2004 - Biosorption of chromium(VI) ion from aqueous solution by the bacterium Bacillus thuringensis. Process Biochemistry. 40(5), 1895-1901.

Sanghi R, Sankararamakrishnan N, Dave BC. 2009 - Fungal bioremediation of chromates: conformational changes of biomass during sequestration, binding, and reduction of hexavalent chromium ions. Journal of Hazardous Materials. 169(1-3), 1074-1080

Saxena P, Bhattacharyya AK, Mathur N. 2006 - Nickel tolerance and accumulation by filamentous fungi from sludge of metal finishing industry. Geomicrobiology Journal. 23(5), 333-340. 
Sharma S, Adholya A. 2011 - Detoxification and accumulation of chromium from tannery effluent and spent chrome effluent by Paecilomyces lilacinus fungi. International Biodeterioration and Biodegradation. 65, 309-317.

Srivastava S, Thakur IS. 2006 - Biosorption potency of Aspergillus niger for removal of Chromium (VI). Current Microbiology. 53(3), 232-237.

Valix M, Tang J Y, Malik R. 2001 - Heavy metal tolerance of fungi. Minerals Engineering. 14(5), 499-505. 